\title{
First study of hepatitis delta virus in Algeria: Seroprevalence and risk factors in Setif region (east of Algeria)
}

\begin{tabular}{|c|c|}
\hline \multicolumn{2}{|c|}{$\begin{array}{l}\text { Authors: } \\
\text { Abdelkader Gasmi }^{1} \\
\text { Wahiba Guenifi }^{1} \\
\text { Amel Ouyahia }^{1} \\
\text { Mounira Rais }^{1} \\
\text { Houda Boukhrissa }^{1} \\
\text { Abderahmen Hachani }^{1} \\
\text { Salah Mechakra } \\
\text { Slimen Laouamri } \\
\text { Abderezak Touabti }^{3} \\
\text { Abdelmadjid Lacheheb }^{1}\end{array}$} \\
\hline \multicolumn{2}{|c|}{$\begin{array}{l}\text { Affiliations: } \\
{ }^{1} \text { Division of Infectious } \\
\text { Diseases Teaching Hospital, } \\
\text { Faculty of Medicine, } \\
\text { University Ferhat Abbes Setif, } \\
\text { Setif, Algeria }\end{array}$} \\
\hline \multicolumn{2}{|c|}{$\begin{array}{l}{ }^{2} \text { Division of Epidemiology } \\
\text { Teaching Hospital, Faculty of } \\
\text { Medicine, University Ferhat } \\
\text { Abbes Setif, Setif, Algeria }\end{array}$} \\
\hline \multicolumn{2}{|c|}{$\begin{array}{l}{ }^{3} \text { Division of Microbiology } \\
\text { Teaching Hospital, Faculty of } \\
\text { Medicine, University Ferhat } \\
\text { Abbes Setif, Setif, Algeria }\end{array}$} \\
\hline \multicolumn{2}{|c|}{$\begin{array}{l}\text { Corresponding author: } \\
\text { Abdelkader Gasmi, } \\
\text { gasmiabdelkader@univ-setif.dz }\end{array}$} \\
\hline \multicolumn{2}{|c|}{$\begin{array}{l}\text { Dates: } \\
\text { Received: } 16 \text { Aug. } 2017 \\
\text { Accepted: } 12 \text { July } 2019 \\
\text { Published: } 23 \text { Oct. } 2019\end{array}$} \\
\hline \multicolumn{2}{|c|}{$\begin{array}{l}\text { How to cite this article: } \\
\text { Gasmi A, Guenifi W, Ouyahia } \\
\text { A, et al. First study of } \\
\text { hepatitis delta virus in } \\
\text { Algeria: Seroprevalence and } \\
\text { risk factors in Setif region } \\
\text { (east of Algeria). S Afr J Infect } \\
\text { Dis. 2019;34(1), a110. } \\
\text { https://doi.org/10.4102/ } \\
\text { sajid.v34i1.110 }\end{array}$} \\
\hline \multicolumn{2}{|l|}{ Read online: } \\
\hline 口+1: & $\begin{array}{l}\text { Scan this QR } \\
\text { code with your } \\
\text { smart phone or } \\
\text { mobile device } \\
\text { to read online. }\end{array}$ \\
\hline
\end{tabular}

Background: No recent data are available on hepatitis delta virus (HDV) prevalence in Algeria. For this reason we conducted an epidemiological study, cross-sectional seroprevalence of HDV in the region of Setif.

Methods: Between 2011 and 2014, sera samples of 500 patients (carrying HBsAg) admitted to the Division of Infectious Diseases Teaching Hospital, Setif (east of Algeria), were tested for anti-HDV-IgG ab (ETI-AB-DeltaK-2).

Results: The prevalence of HDV obtained is estimated at $2.4 \%$. The prevalence ranges from $1 \%$ in chronic hepatitis to $11.1 \%$ in cirrhotic hepatitis (low endemic area). Seropositivity rate is closely correlated with age (Odds ratio $[\mathrm{OR}]=9.98, p=0.000)$ and gender $(\mathrm{OR}=0.24, p=0.025)$; it reaches $58.3 \%$ in the age group of 51-60 years and $0 \%$ in children (age group 1-15 years); it represents $75 \%$ in females and $25 \%$ in males. The presence of familial cases of HBsAg positive $(\mathrm{OR}=4.54, p=0.006)$, the endoscopic procedure $(\mathrm{OR}=6.54, p=0.000)$ and tattooing $(\mathrm{OR}=20$, $p=0.000$ ) were found to be the transmission risk factors. A statistically significant relationship was found between the positivity of anti-HDV and advanced liver disease, cirrhosis $(\mathrm{OR}=9.16$, $p=0.000)$. A significant correlation was found between the positivity of anti-HDV with diabetes $(\mathrm{OR}=6.83, p=0.000)$, obesity $(\mathrm{OR}=4.19, p=0.009)$ and viral suppression $\mathrm{B}(\mathrm{OR}=5.69$, $p=0.003)$.

Conclusion: Our results show that HDV infection is low in Algeria. Research for total antiHDV should be part of the initial assessment of patient care with viral hepatitis B as well as the prevalence of other viruses (hepatitis C [HCV] and HIV). A multicentre study should be carried out to know the importance of HDV infection and identify the risk groups.

Keywords: Hepatitis Delta Virus; prevalence; risk factors; Setif; Algeria.

\section{Introduction}

First described in 1977 by Rizzetto et al., ${ }^{1}$ the hepatitis delta virus (HDV) is a small virus $1.7 \mathrm{~kb}$ RNA, single-stranded, negative polarity considered a human agent. Biological characteristics not fully completing the virus definition criteria and its dependence on a helper virus ${ }^{2}$ has placed it under the satellite virus group. ${ }^{3}$ In 1993, the International Committee on Taxonomy of Viruses proposed to classify it in a member of the free-floating genus Deltavirus ${ }^{4}$ of which it is the sole representative. ${ }^{5}$ One of its characteristics is its high genetic variability with eight separate genotypes HDV (HDV18). ${ }^{6,7}$ Hepatitis delta is an ubiquitous transmissible infection, reported in every country in which it was sought. ${ }^{8,9}$ Nevertheless, there is a varying prevalence from one country to another country and from one region to another region within the same country. Early studies in the eighties have found a mean prevalence estimated at $5 \%$ in the carrier population of $\mathrm{HBs} \mathrm{Ag}$.

Hepatitis delta infection remains a major public health problem, and it is currently estimated that, worldwide, between 15 and 20 million people are positive for the viral hepatitis delta (VHD) and it affects all ages, but its distribution is not uniform. ${ }^{10,11}$ The epidemiology of HDV has changed; in fact, factors such as vaccination and public health measures against acquired immunodeficiency syndrome (AIDS) combined with improvements in hygienic conditions have contributed to control the hepatitis $\mathrm{B}$ virus infection and, as a direct consequence, the decrease in the prevalence of infection with HDV. ${ }^{12,13}$

Algeria is exposed to the risk of reintroduction by migrants, that is, neighbours, coming mainly from its southern countries: $29 \%$ in Niger, ${ }^{14} 19.7 \%$ in Mauritania ${ }^{15}$ and $13.9 \%$ in Mali. ${ }^{16}$ Furthermore,

Copyright: @ 2019. The Authors. Licensee: AOSIS. This work is licensed under the Creative Commons Attribution License. 


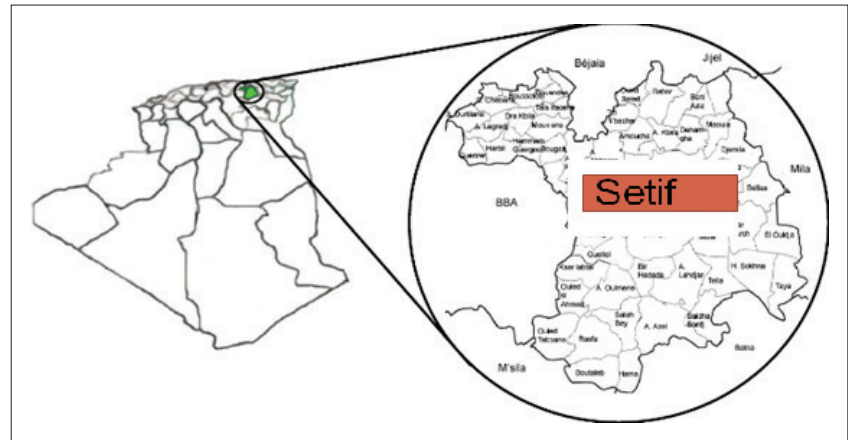

Source: Mouffok CE. Diversité des systèmes délevage bovin laitier et performances animales en région semi-aride de Setif. Thèse de Magister en sciences animales 1997. Alger: Institut national agronomique (INA)

FIGURE 1: Location of Setif city. ${ }^{17}$

we noted the presence of new genotypes such as the VHD5 genotype that represents $10.7 \%$ of isolated strains in Mauritania. $^{7}$

In Algeria, the epidemiology of this hepatitis is still very little known. Only four studies were conducted on limited numbers and populations. For this reason, we conducted a cross-sectional seroprevalence study of HDV in the Setif region (Figure 1). ${ }^{17}$

\section{Materials and methods}

Between 2011 and 2014, sera samples of 500 patients (carrying HBsAg) admitted to the Division of Infectious Diseases Teaching Hospital, Setif (east of Algeria), were tested for antiHDV-IgG ab (ETI-AB-DeltaK-2). The patients are from five cities in the east of Algeria (Setif, Bourdj-Bou-Arrerdj, Msila, Mila and Bejaia).

Inclusion criteria: All HBsAg patients in this study at the Division of Infectious Diseases Teaching Hospital, Setif.

Exclusion criteria: Patients refusing to participate.

A questionnaire was completed for each patient including information about age, sex, marital status, number of wives and children, socio-economic level, risk exposure during life, discovery circumstances, comorbidity and specific situations such as, overweight and obesity, diabetes, pregnancy, history of hemodialysis and co-infection with $\mathrm{HCV}$ and co-infection with HIV.

Results in clinical and biochemical examinations data were correlated with those of the HBV viral load. According to the stage of their liver disease, patients were divided into four groups: first group, acute hepatitis B; second group, chronic hepatitis B; third group, cirrhosis; and fourth group, hepatocellular carcinoma.

\section{Statistical analysis}

Data analysis was performed using SPSS version 21.0 (SPSS Inc., USA). We used the technique of descriptive statistics with the estimated prevalence with a confidence interval
(CI) ww 95\%; chi-square test and Fishers exact test were used for the comparison of distributions and calculation of measures of epidemiological associations (odds ratio [OR]) with $95 \%$ CI. A p-value $<0.05$ was considered significant.

\section{Ethical consideration}

The study was approved by the research ethical committee of University Ferhat Abbes Setif, Algeria. All participants gave their consent before data and blood samples were collected.

\section{Results}

The study of 500 sera samples from patients with HBsAg in different stages of the disease shows 12 patients having antidelta positive total IgG, a prevalence equal to $2.4 \%$ with a $95 \%$ CI $[1.1 \%-3.7 \%]$.

The prevalence of HDV is higher among women $(75 \%$ of positive anti-HDV). The difference was statistically significant $(\mathrm{OR}=0.24, p=0.025)$ (Table 1$)$.

The average age of patients with VHD $(55.5 \pm 12.5$ years $)$ is significantly higher than that of patients infected with HBV alone (38.56 \pm 15.5 years), and the difference was statistically significant $(p=0.000)$.

The city of Msila displays the highest rate of $6.9 \% 0 \%-17.2 \%$, followed by the city of Bourdj-Bou-Arrerdj with a rate of $2.9 \%$ $0 \%-7.2 \%$ and the city of Setif with a rate of $2 \% 0.8 \%-3.5 \%$. In the city of Bejaia and Mila, the prevalence rate is zero (Table 2).

Statistical analysis revealed a significant relationship between marital status and positivity of anti-HDV $(\mathrm{OR}=1.03, p=0.03)$, but there was no relationship between the number of wives and positivity of anti-HDV. The average number of children in patients with VHD (4.83 \pm $2.65)$ is significantly higher than that of those infected with $\mathrm{HBV}$ alone $(2.83 \pm 2.31)$, and the difference is statistically significant $(\mathrm{OR}=1.03, p=0.004)$. A significant relationship was found between certain risk factors and transmission (the positive family history of hepatitis B OR $=4.54$, $p=0.006$, endoscopy OR $=6.54, p=0.000$, tattoos $\mathrm{OR}=20$, $p=0.000)$ (Tables 1 and 3).

Significant relationship between viral hepatitis delta and some of these factors investigated was found, such as number of children $(\mathrm{OR}=5.6, p=0.001)$ and obesity $(\mathrm{OR}=4.19, p=0.000)($ Table 1$)$.

Diabetes $(\mathrm{OR}=6.83, p=0.000), \operatorname{ALT}(\mathrm{OR}=6.9, p=0.005)$ and HVB DNA (OR $=5.69, p=0.003$ ) were correlated with antiHDV serology antibodies (positive or negative) (Table 1).

Prevalence of HDV seropositivity varies according to the liver disease stages: acute hepatitis (3.6\%) with a 95\% CI $0 \%$ $-9 \%$, chronic hepatitis (1\%) with a $95 \%$ CI $0 \%-2 \%$, cirrhosis (11.1\%) with a 95\% CI $1.8 \%-20.3 \%$ and hepatocellular carcinoma (0\%) (Table 4$)$. 
TABLE 1: Relationship with demographic characteristics, diabetes, pregnancy, history of hemodialysis, co-infection with HCV or HIV, biological and virological parameters and hepatitis delta virus.

\begin{tabular}{|c|c|c|c|c|c|c|c|}
\hline \multirow[t]{2}{*}{ Variable } & \multicolumn{2}{|c|}{ IgG-anti-delta positivity } & \multicolumn{2}{|c|}{ IgG-anti-delta negativity } & \multirow[t]{2}{*}{$P$} & \multirow[t]{2}{*}{ OR } & \multirow[t]{2}{*}{ OR: Min-Max } \\
\hline & Positive & $\%$ & Negative & $\%$ & & & \\
\hline \multicolumn{8}{|l|}{ Age } \\
\hline Mean of age & $55.5 \pm 12.5$ & - & $38.5 \pm 15.5$ & - & 0.000 & - & - \\
\hline Age group (51-60) & 7 & 58.3 & 10 & 83.3 & 0.000 & 10.0 & $3-32.5$ \\
\hline \multicolumn{8}{|l|}{ Gender } \\
\hline Male & 3 & 25 & 281 & 57.6 & 0.025 & 5.0 & $0.06-0.9$ \\
\hline Female & 9 & 75 & 207 & 42.4 & - & - & - \\
\hline \multicolumn{8}{|l|}{ Marital status } \\
\hline Single & 0 & 0 & 132 & 27.9 & 0.03 & 1.03 & $1.01-1.05$ \\
\hline Married & 12 & 100 & 341 & 71.1 & - & - & - \\
\hline \multicolumn{8}{|l|}{ Number of children } \\
\hline Means \pm SD & $4.83 \pm 2.65$ & - & $2.83 \pm 2.31$ & - & 0.004 & - & - \\
\hline$\geq 5$ & 7 & 58.3 & 68 & 19.9 & 0.001 & 5.6 & $1.7-18.2$ \\
\hline \multicolumn{8}{|l|}{ Profession } \\
\hline Unemployed & 10 & 83.3 & 259 & 53.1 & 0.03 & 4.4 & $0.9-20.3$ \\
\hline Officials & 1 & 8.3 & 68 & 18 & 0.38 & - & - \\
\hline Liberal officials & 1 & 8.3 & 85 & 17.4 & 0.41 & - & - \\
\hline Students & 0 & 0 & 43 & 8.8 & 0.28 & - & - \\
\hline Health workers & 0 & 0 & 13 & 2.7 & 0.32 & - & - \\
\hline \multicolumn{8}{|l|}{ BMI $\left(\mathrm{Kg} / \mathrm{m}^{2}\right)$} \\
\hline \multicolumn{8}{|l|}{ Means \pm SD } \\
\hline Overweight (BMI: 25.00-29.99) & 2 & 16.7 & 173 & 36.6 & 0.15 & 0.3 & $0.1-1.6$ \\
\hline Obesity (BMI $\geq 30$ ) & 6 & 50.5 & 91 & 19.2 & 0.009 & 4.1 & $1.3-13.3$ \\
\hline Diabetes & 5 & 10.6 & 46 & 9.4 & 0.000 & 6.9 & $2-22$ \\
\hline Pregnancy & 0 & 0 & 31 & 15 & 0.20 & - & - \\
\hline History of hemodialysis & 0 & 0 & 12 & 2.6 & 0.58 & - & - \\
\hline Co-infection with HCV & 1 & 8.3 & 26 & 5.3 & 0.64 & - & - \\
\hline Co-infection with HIV & 0 & 0 & 3 & 0.6 & 0.87 & - & - \\
\hline \multicolumn{8}{|l|}{ ALT (IU/L) } \\
\hline Means $\pm S D$ & $52.6 \pm 19$ & - & $45 \pm 44.7$ & - & 0.62 & - & - \\
\hline$>40$ & 8 & 80 & 159 & 36.6 & 0.005 & 6.9 & $7.3-160.4$ \\
\hline \multicolumn{8}{|l|}{ Platelets $\left(\mathrm{n} / \mathrm{mm}^{3} \times 10^{6}\right)$} \\
\hline Means \pm SD & $172 \pm 89$ & - & $200 \pm 81$ & - & 0.23 & - & - \\
\hline$<150000$ & 7 & 58.3 & 352 & 72.1 & 0.29 & 34.3 & $7.3-160.4$ \\
\hline HBeAg positivity & 1 & 33.3 & 72 & 26.6 & 0.79 & - & - \\
\hline \multicolumn{8}{|l|}{ Serum HBV DNA } \\
\hline$<100 \mathrm{IU} / \mathrm{mL}$ & 5 & 50 & 65 & 14.9 & 0.003 & 5.7 & $1.6-20.2$ \\
\hline$>4.3 \log (10)$ copies $/ \mathrm{mL}$ & 2 & 20 & 102 & 23.4 & 0.78 & - & - \\
\hline
\end{tabular}

ALT, alanine transaminase; PLT, platelets; SD, standard deviation; OR, odds ratio; Min, minimum; Max, maximum.

TABLE 2: Prevalence of HDV by city.

\begin{tabular}{lccccc}
\hline City & $\boldsymbol{N}$ & $\mathbf{\%}$ & \multicolumn{2}{c}{ IgG-anti-delta+ } & $\boldsymbol{P}$ \\
\cline { 5 - 6 } & & & Positive & $\mathbf{\%}$ & \\
\hline Setif & 394 & 78.8 & 8 & 2.0 & 0.29 \\
Bourdj-Bou-Arrerdj & 69 & 13.8 & 2 & 2.9 & 0.77 \\
Msila & 29 & 5.8 & 2 & 6.9 & 0.10 \\
Mila & 4 & 0.8 & 0 & 0.0 & 0.75 \\
Bejaia & 4 & 0.8 & 0 & 0.0 & 0.75 \\
\hline Total & $\mathbf{5 0 0}$ & $\mathbf{1 0 0}$ & $\mathbf{1 2}$ & $\mathbf{1 0 0}$ & - \\
\hline
\end{tabular}

\section{Discussion}

This study demonstrates that Algeria is in a low endemic region for VHD. The available data studies on hepatitis delta are exposed in Table $5 .{ }^{18,19}$

Our prevalence is comparable to those found in most of the Maghreb countries (Tunisia: 6.8\%, ${ }^{20}$ Egypt: $4.7 \%,{ }^{21}$ Morocco: $1.17 \%{ }^{22}$ and Libya: $10.8 \%{ }^{23}$ ).

In contrast to our results, Mauritania shows a high prevalence of $19.7 \%,{ }^{15}$ and in Central Africa, Makuwa ${ }^{24}$ has reported a very high prevalence of $66.7 \%$ in Gabon, recalling the first outbreaks of hepatitis delta described in the 1980s in the Central African Republic. ${ }^{25}$ In most countries of West Africa, ${ }^{26}$ especially those sharing borders with Algeria, high rates are recorded. Our prevalence is above that reported by Dusheiko in South Africa ${ }^{27}$ (0.6\%) (Figure 2).

Our results are lower than the higher rates reported in Italy; as in several European countries, Italy has witnessed a significant decrease in its VHD infection rates. ${ }^{12,28}$

This study allowed us to have updated information about the infection in at least three cities. The prevalence varies from one city to another. This difference in prevalence between the three cities may be related to the incidence of viral hepatitis B (estimated in Algeria at 2.16\%, and 2.68\% in Msila city). ${ }^{29,30}$ This same observation was reported by $\mathrm{Djebbi}^{20}$ in Tunisia.

The prevalence of hepatitis D (HVD) in Algeria is closely related to gender and age. In most studies, a male predominance has been noted ${ }^{8,29}$ with the exception of some countries or some regions. More recently, the Hepatitis Delta 
TABLE 3: Relationship with risk factors and hepatitis delta virus.

\begin{tabular}{|c|c|c|c|c|c|c|c|}
\hline \multirow[t]{2}{*}{ Variable } & \multicolumn{2}{|c|}{ IgG-anti-delta positivity } & \multicolumn{2}{|c|}{ IgG-anti-delta negativity } & \multirow[t]{2}{*}{$P$} & \multirow[t]{2}{*}{ OR } & \multirow[t]{2}{*}{$\chi^{2}$ test } \\
\hline & Positive & $\%$ & Negative & $\%$ & & & \\
\hline Dental procedures & 10 & 83.3 & 397 & 81.4 & 0.86 & 1.1 & 0.03 \\
\hline Blood transfusion & 3 & 25 & 123 & 25.2 & 0.98 & 0.9 & 0.20 \\
\hline Surgery & 8 & 66.7 & 235 & 48.2 & 0.20 & 0.9 & 1.6 \\
\hline Endoscopy & 7 & 58.3 & 86 & 17.6 & 0.000 & 6.5 & 12.8 \\
\hline Sexual & 3 & 58.3 & 62 & 12.7 & 0.21 & 2.2 & 1.56 \\
\hline Positive family History & 7 & 58.3 & 115 & 23.6 & 0.006 & 4.5 & 7.67 \\
\hline blood exposure accident & 0 & 0.0 & 16 & 3.3 & 0.52 & 0.97 & 0.40 \\
\hline Percutaneous exposure (shaving at a barbers shop) & 3 & 25 & 300 & 61.5 & 0.011 & 0.2 & 6.52 \\
\hline Tattoo history & 3 & 25 & 8 & 1.6 & 0.000 & 20 & 29.7 \\
\hline Piercing & 1 & 8.3 & 5 & 1 & 0.02 & 20 & 5.27 \\
\hline Not identified & 0 & 0.0 & 13 & 2.7 & 0.56 & 0.97 & 0.32 \\
\hline
\end{tabular}

OR, odds ratio.

TABLE 4: Prevalence of hepatitis delta virus infection among hepatitis B virus (HBV) infected subjects with liver disease.

\begin{tabular}{|c|c|c|c|c|c|c|}
\hline \multirow[t]{2}{*}{ HBV-related liver disease group } & \multirow[t]{2}{*}{$n$} & \multicolumn{2}{|c|}{ IgG-anti-delta positivity } & \multirow[t]{2}{*}{$P$} & \multirow[t]{2}{*}{$95 \% \mathrm{Cl}$} & \multirow[t]{2}{*}{$\mathrm{OR}$} \\
\hline & & Positive & $\%$ & & & \\
\hline Acute hepatitis & 55 & 2 & 3.6 & 0.52 & $0-9$ & - \\
\hline Chronic hepatitis & 384 & 4 & 1 & 0.000 & $0-2$ & 0.2 \\
\hline Cirrhosis & 54 & 6 & 11.1 & 0.000 & $1.8-20.3$ & 9.6 \\
\hline Hepatocellular carcinoma & 7 & 0 & 0.0 & 0.67 & - & - \\
\hline Total & 500 & 12 & - & - & - & - \\
\hline
\end{tabular}

OR, odds ratio.

TABLE 5: Prevalence of viral hepatitis delta in Algeria.

\begin{tabular}{|c|c|c|c|c|c|c|c|c|c|c|}
\hline \multirow[t]{2}{*}{ Study } & \multicolumn{2}{|c|}{ Acute hepatitis } & \multicolumn{2}{|c|}{ Chronic hepatitis } & \multicolumn{2}{|c|}{ Cirrhosis } & \multicolumn{2}{|c|}{ Hepatocellular carcinoma } & \multicolumn{2}{|c|}{ Prevalence } \\
\hline & $\%$ & Positive $(n)$ & $\%$ & Positive $(n)$ & $\%$ & Positive $(n)$ & $\%$ & Positive $(n)$ & $\%$ & Positive $(n)$ \\
\hline Nouasria 1984 & 6 & $3 / 50$ & - & - & - & - & - & - & 6 & $3 / 50$ \\
\hline Belabbes 1986 & 3.7 & $3 / 81$ & 16.6 & $1 / 16$ & 15.1 & $5 / 33$ & - & - & 7.5 & $9 / 120$ \\
\hline Berkane 2003 & - & - & 6.81 & $3 / 44$ & - & - & - & - & 6.81 & $3 / 44$ \\
\hline Khelifa 2009 & - & - & 1.33 & $1 / 75$ & - & - & - & - & 1.33 & $1 / 75$ \\
\hline Our study & 3.6 & $2 / 53$ & 1 & $4 / 384$ & 11.1 & $6 / 54$ & 0 & $0 / 7$ & 2.4 & $12 / 500$ \\
\hline
\end{tabular}

International Network (HDIN) Register ${ }^{31}$ which includes 12 worldwide study centres for delta hepatitis, reported results showing predominance of one gender over the other according to the patient origin.

This study has provided us with some information on the exposure of risk factors in life. The presence of the family cases of viral hepatitis B is one of the found risk factors which is in agreement with that reported by Fattovich ${ }^{32}$ in Italy $(8.1 \%, p=0.004)$.

The second risk factor found was the endoscopic procedure. Few studies have focused on this mode of transmission. Our results are in agreement with those of Gheorghe in Romania ${ }^{33}$ $(36.8 \%, p=0.0001)$.

The risk of virus transmission during endoscopy is low, because the cleaning and disinfection practice insures a significant viral inactivation. ${ }^{34}$

Thirdly, tattooing was found to be a significant risk factor in patients with VHD.

During tattooing, the muco-cutaneous barrier is broken accompanied by a break of blood capillaries, leading a moderate and transient bleeding which is enough exposure to the risk of infections with hepatitis viruses or HIV.

Traditional methods of tattooing and poor hygiene practices contribute mainly to the increased risk of transmission. Exposure to other risk factors is not significant.

This is the only study that was interested in the association of delta hepatitis and diabetes. The diabetic population is being exposed to a multiplicity of risk factors for hepatitis; furthermore, diabetes favours the development of severe forms of liver disease (cirrhosis and hepatocellular carcinoma).

Our study sheds light on the prevalence of hepatitis delta virus at different stages of liver disease. This rate is consistent with that found by Belabbes ${ }^{18}$ who has reported a prevalence of $15.15 \%$ (5/33). Several authors have noted the frequency of anti-HDV antibodies in patients at the cirrhosis stage. ${ }^{35}$

In conclusion, our results show that HDV infection is low in Algeria.

Research for total anti-HDV should be part of the initial assessment of patient care with viral hepatitis B as well 


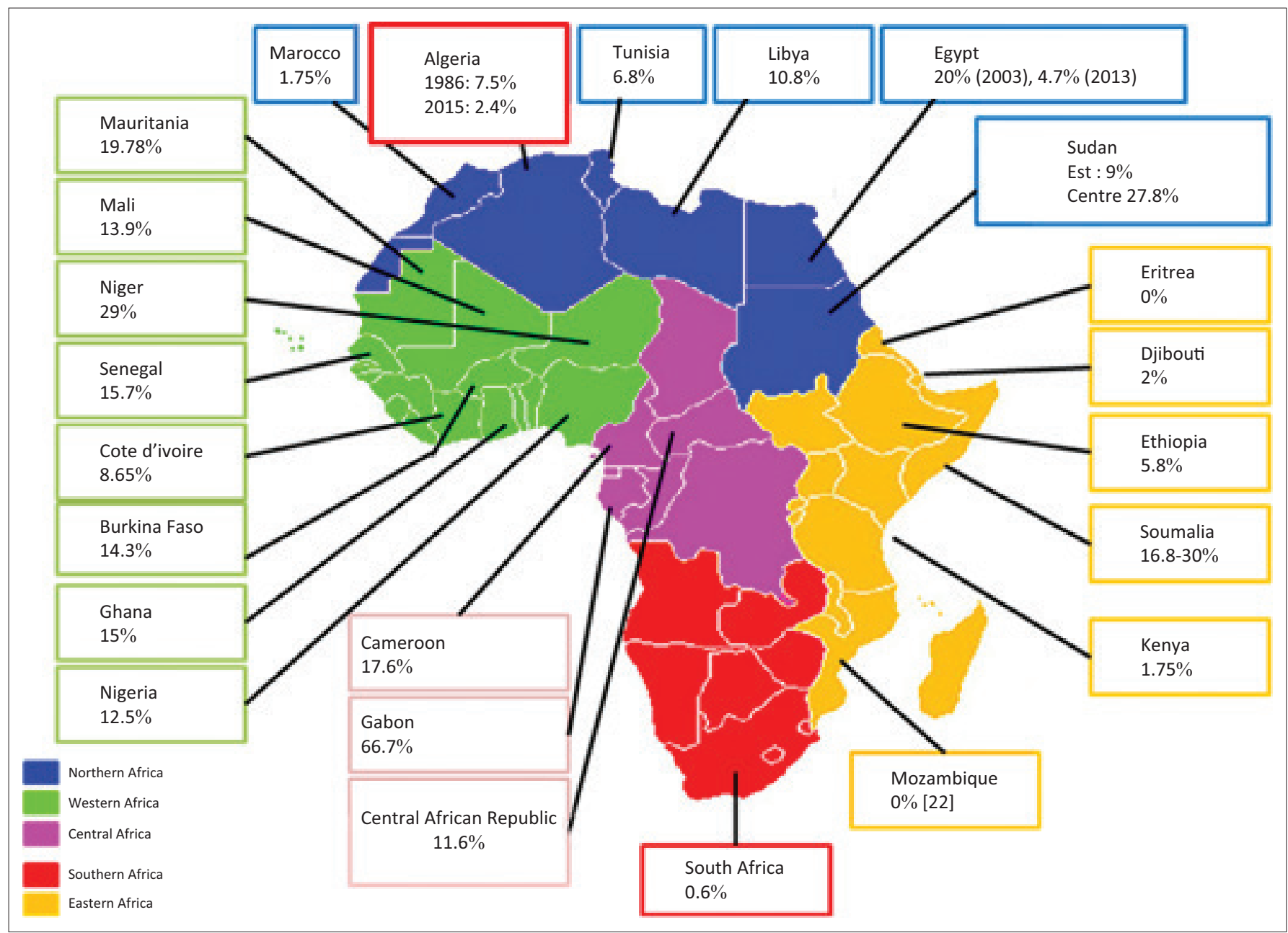

FIGURE 2: Prevalence of hepatitis delta in Africa.

as the search of other viruses (HCV and HIV), and the completion of a multicentre study should be carried out to establish the prevalence of HDV and identify the risk groups.

\section{Acknowledgement}

\section{Competing interests}

The authors have declared that they have no conflicts of interest.

\section{Authors' contributions}

All authors contributed equally to this study.

\section{Funding information}

This research received no specific grant from any funding agency in the public, commercial or not-forprofit sectors.

\section{Data availability statement}

Data sharing is not applicable to this article as no new data were created or analysed in this study.

\section{Disclaimer}

The views and opinions expressed in this article are those of the authors and do not necessarily reflect the official policy or position of any affiliated agency of the authors.

\section{References}

1. Rizzetto M, Canese MG, Arico J, et al. Immunofluorescence detection of a new antigen-antibody system (delta/anti-delta) associated to the hepatitis B virus in the liver and in the serum of HBsAg carriers. Gut. 1977;18:997-1003. https://doi. org/10.1136/gut.18.12.997

2. John T. Origin of hepatitis $\delta$ virus. Future Microbiol. 2010;5:393-402. https://doi. org $/ 10.2217 / \mathrm{fmb} .10 .15$

3. Flores R, Ruiz S, Serra P. Viroids and hepatitis delta virus. Semin Liver Dis. 2012;32(3):201-210. https://doi.org/10.1055/s-0032-1323624

4. ICTV (International Committee of Taxonomy of Virus). Taxonomy history for Hepatitis delta virus. c2013 [cited 2017 Aug 23]; Available from: http://ictvonline. org/virusTaxonomy.asp.

5. Rizzetto M, Ciancio A. Hepatitis D. In: Boyer TD, Manns MP, Sanyal AJ, editors. Zakim and Boyers hepatology: A textbook of liver disease. 6th ed. Philadelphia, PA: Saunders, 2012; p. 599-604.

6. Dény P. Hepatitis delta virus genetic variability: From genotypes I, II, III to eight major clades. In: Casey JL, editor. Hepatitis delta virus. Heidelberg: Springer, 2006; p. 151-171.

7. Radjef N, Gordien E, Ivaniushina V. Molecular phylogenetic analyses indicate a wide and ancient radiation of African hepatitis delta virus, suggesting a deltavirus genus of at least seven major clades. J Virol. 2004;78(5):2537-2544. https://doi. org/10.1128/JVI.78.5.2537-2544.2004

8. Gordien E. L'infection par le virus de l'hépatite delta. Données françaises récentes. Bull Epidémiol Hebd. 2015;19-20:347-352. 
9. Wedemeyer H. Chapter 10: Hepatitis D - Diagnosis and treatment. In: Hepatology a clinical textbook. Flying Publisher; 2014. [cited 2015 Jan 01]; Available from: https://www.google.com/url?sa=t\&rct=j\&q=\&esrc=s\&source=web\&cd $=3 \&$ ved $=2$ ahUKEwj30eC4m4_IAhVqTxUIHUV-AlgQFjACegQIAxAC\&url=https\%3A\%2F\%2Fw ww.medbox.org\%2Fhepatology-a-clinical-textbook\%2Fdownload.pdf\&usg=AOvV
aw0QJQueG3wnkW4PEIfkgDJh.

10. Hughes SA, Wedemeyer $H$, Harrison PM. Hepatitis delta virus. Lancet. 2011;378:73-85. https://doi.org/10.1016/S0140-6736(10)61931-9

11. Farci P. Delta hepatitis: An update. J Hepatol. 2003;39:S212-S219.

12. Gaeta GB, Stroffolini T, Chiaramonte M, et al. Chronic hepatitis D: A vanishing disease? An Italian multicenter study. Hepatology. 2000;32:824-827. https://doi. org/10.1053/jhep.2000.17711

13. Rizzetto M, Alavian SM. Hepatitis delta: The rediscovery. Clin Liver Dis. 2013;17:475-487. https://doi.org/10.1016/j.cld.2013.05.007

14. Soubiran G, Cenac A, Lebras M. Approche épidémiologique des affections virus $B$ et delta au Niger. Populations Et Sante Tropicales. 1987;28:1-2.

15. Mansour W, Bollahic M-A, Hamed, C-T, et al. Virological and epidemiological features of hepatitis delta infection among blood donors in Nouakchott, Mauritania. J Clin Virol. 2012;55:12-16. https://doi.org/10.1016/j.jcv.2012. 05.011

16. Diarra A, Kouriba B, Baby M, Murphy E, Lefrere JJ. HIV, HCV, HBV and syphilis rate of positive donations among blood donations in Mali: Lower rates among volunteer blood donors. Transfus Clin Biol. 2009;16:444-447. https://doi. org/10.1016/j.tracli.2009.09.004

17. Mouffok CE. Diversité des systèmes délevage bovin laitier et performances animales en région semi-aride de Setif. Thèse de Magister en sciences animales 1997. Alger: Institut national agronomique (INA).

18. Belabbes EH.The hepatitis delta virus in Algiers (Algeria). Prog Clin Biol Res. 1987;234:443-444.

19. Khelifa F, Thibault V. Caractéristiques des souches virales responsables dhépatites B chroniques en Algérie du Nord-Est. Pathol Biol. 2009;57:107-113. https://doi. org/10.1016/j.patbio.2008.07.031

20. Djebbi A, Rebai WK, Bahri O, Hogga N, Sadraoui A, Triki H. Serological markers, viral RNA and genotype of hepatitis delta virus in HBs antigen positive Tunisian patients. Pathol Biol. 2009;57:518-523. https://doi.org/10.1016/j. patbio.2008.09.010

21. Nahed IG, Lobna AM, Nader N, Soha Y. Seroprevalence of HDV infection in $\mathrm{HBsAg}$ positive population in Ismailia, Egypt. Egypt J Immunol. 2013 ; 20(1):23-28.
22. Rioche M. Low occurrence of delta agent infections in Morocco. Bull Soc Pathol Exot Filiales. 1987;80(5):741-744.

23. El Haasi. Delta Hepatitis. Mononthematic Conference Istanbul EASL; 2010.

24. Makuwa M, Mintsa-Ndong A, Souquiere S, Nkoghe D, Leroy EM, Kazanji M Prevalence and molecular diversity of hepatitis $B$ virus and hepatitis delta virus in urban and rural populations in northern Gabon in central Africa. $J$ Clin Microbiol. 2009;47:2265-2268. https://doi.org/10.1128/JCM.02012-08

25. Lesbordes JL, Musse P, Georges AJ, et al. Studies on the role of HDV in an outbreak of fulminant hepatitis in Bangui (Central African Republic). Prog Clin Biol Res. 1987;234:451-459.

26. Iris EA, Lukas VL, Zekiba ST, et al. Characterization of Hepatitis Delta Virus in SubSaharan Africa. J Clin Microbiol. 2014;52(5):1629-1636. https://doi.org/10.1128/ JCM.02297-13

27. Dusheiko GM, Brink BA, Conradie JD, Marimuthu T, Sher R. Regional prevalence of hepatitis $B$, delta, and human immunodeficiency virus infection in southern Africa: A large population survey. Am J Epidemiol. 1989;129(1):138-145. https:// doi.org/10.1093/oxfordjournals.aje.a115102

28. Niro GA, Smedile A, Ippolito AM, et al. Outcome of chronic delta hepatitis in Italy: A long-term cohort study. J Hepatol. 2010;53(5):834-840. https://doi. org/10.1016/j.jhep.2010.06.008

29. Boumansour N, Midoun N, Mallem L, Hakem S. Profil épidémiologique de Ihépatite virale B à louest Algérien, 2010-2012. Revue d'Epidémiologie et de Santé Publique. $2016 ; 64$ (Supplément 4):S207.

30. Berkane S. Prise en charge de l'hépatite chronique virale. Santé-Mag. 2012 Janvier No. 02;36-37.

31. Hardtke S, Abbas Z, Hamid S, et al. Global epidemiology of hepatitis delta: First data from the hepatitis delta international network. Poster 0638.EASL 2015. 50th the International Liver Congress TM 2015. J Hepatol. 2015;62:S558.

32. Fattovich G, Giustina G, Christensen E, et al. Influence of hepatitis delta virus infection on morbidity and mortality in compensated cirrhosis type B. Gut. 2000;46:420-426. https://doi.org/10.1136/gut.46.3.420

33. Gheorghe L, Csiki IE, lacob S, et al. Hepatitis delta virus infection in Romania: Prevalence and risk factors. J Gastrointestin Liver Dis. 2015;24(4):413-421. https://doi.org/10.15403/jgld.2014.1121.244.dtv

34. Bernard $M$, Lionel $P$. Risque infectieux exogène en endoscopie digestive. Revue Francophone des Laboratoires. 2005;376:67-73.

35. Fattovich G, Boscaro $S$, Noventa $F$, et al. Influence of hepatitis delta virus infection on progression to cirrhosis in chronic hepatitis type B. J Infect Dis. 1987;155:931-935. https://doi.org/10.1093/infdis/155.5.931 